\title{
The Biblical Analysis of The Return of the Native
}

\author{
ZHANG Liu, HUA Yan \\ University of Shanghai for Science and Technology, Shanghai, China
}

\begin{abstract}
The Bible is an important source for the composition of American and English literature works, making them vivid, fruitful, and pregnant. The Return of the Native, written by Thomas Hardy (1955), which possesses strong religious color, quotes many biblical prototypes and biblical concepts to help the construction of characters, and reveals the view of Hardy to the Bible. Thus, this paper focuses on the quotations of the Bible in The Return of the Native to debate about the profound significance of Biblical quotations in character image, atmosphere creation, and artistic effect of the novel as well as what author wants to express.
\end{abstract}

Keywords: The Bible, The Return of the Native, religious color

\section{Introduction}

Thomas Hardy (1840-1928) composed more than 20 novels, some of which were embedded in deep religious color. Since his early age, Hardy had spent his life in the religious family, reciting biblical knowledge and well knowing about biblical doctrines. Though in late years, his attitude towards religion took some slim changes, he still injected many Christian elements into his works so that he thought back to old biblical traditions as well as enriched his design of plots and themes of the novels. Among Hardy's novels, there are 14 novels containing over 600 biblical allusions, the largest number, 87, occurring in Hardy's novel, but two, Tess. Four novels, Far From the Madding Crowd, The Return of the Native, Tess and Jude, exceed 60 references; The Trumpet-Major and The Well-Beloved have fewer than 20 (ZHU, 1982). Through a review of research on Hardy's novels, some researchers have conducted analysis of biblical elements in Hardy's novels, especially for Tess of the D'Urbervilles and Tess and Jude. For the novel, The Return of the Native, rich in religious information, totally including almost 50 biblical quotations, few of researchers systematically made detailed analysis of biblical elements in that novel. This paper aims at the specific biblical elements by analyzing the plot, character, atmosphere, theme, and literariness of The Return of the Native at the backdrop of Western biblical literature and Christian culture and Hardy's personal view of the Christian philosophy. Some scholars pointed out Hardy incorporates various minds, including belief, skepticism, rebel, and introspection in his attitude to Christianity (MA, 2003), and thus we may trace into his view to Christian doctrines in The Return of the Native so that readers can further their appreciations of Hardy's works.

\section{The Bible in Western Literature}

The Bible has ample contents, not only in its theology, but for its literariness, giving ideas about universe, nature, society, and life. Because of various literature qualities, the Bible exerts great influence on the creation

ZHANG Liu, postgraduate, literature master, Foreign Languages Department, University of Shanghai for Science and Technology.

HUA Yan, associate professor, M.A., Foreign Languages Department, University of Shanghai for Science and Technology. 
of works (LIANG, 2008). The Bible is a maternal theme of literary works, where foreign writers can extract endless sources from the house (CHEN, 1999). Literary quotations, image prototypes, and thematic thoughts in the Bible are sources for authors to choose in the creations of their works. Like William Shakespeare, John Milton, John Donne, and some other literature creators before Thomas Hardy, they were used to infusing Biblical elements into their works or even deliberately from Biblical stories. Relying on the performance of Biblical image and transmission of Biblical spirit, those ambiguous ideas can be sent out, echoed and resonant in each reader. Western men of letters are rejoiced in conveying their religious thought and soliciting inspiration from the Bible, and thus to better understand the intention of those authors and analyze the structure and expressiveness of works, more focus should be put on Biblical elements in Western literature. As I have said before, Hardy, who developed in religious environment and was educated by biblical cultures, used the Bible as a literature weapon in his works to utter minds. The Bible literature became essential components of Hardy's works, complementing and pushing Hardy's composition to a new altitude.

\section{Biblical Quotations in The Return of the Native}

The Biblical prototypes emerge mostly in The Return of the Native, such as Belshazzar, David, Jacob, Saul, Lazarus, serpent, assumption of the virgin, John the Baptist, and some other biblical images. They impose a profound biblical implication on the decoding meaning of this novel. Meanwhile Hardy quotes many interesting stories, for example, Israeli escapes Egypt; Judas and Jesus are at the trail scene; Adam and Eve are extruded from the Garden of Eden. As I pointed before, He used to copy biblical verses in the creation of his own works, all of which reveals his recollection of old Christian convention and his personal religious pursuit. There are more than 50 biblical quotations in the The Return of the Native. So a detailed analysis of the biblical elements in the target novel is an effective way to better appreciate the novel itself and find Hardy's living in such a religious coat.

\section{Analysis of Characters From the Perspective of Biblical Philosophy}

The Return of the Native makes portrayal of different characters. They are all parts of Edgon Heath in which religious cultures and customs spread. People there live together in old Christian convention and hold faith in God. They keep in relationship by biblical philosophy and maintain that tradition that lasts so long.

(1) "They were the bonfires of other of other parishes and hamlets that were engaged in the same sort of commemoration" (Thomas, 1955, p. 14).

Quote from The Custom of the Country in the Chapter 1

(2) "To relieve the tedium of this untimely day she would overhaul the cupboards containing her grandfather's old charts and other rubbish, humming Saturday-night ballads of the country people" (Thomas, 1955, p. 79).

Quote from Queen of Night in the Chapter 1

(3) "Most of them were sitting round the room in seats divided by wooden elbows likthose of crude stalls, which were carved with the initials of many an illustrious drunk-ard of former times who had passed his days and his nights between them, and now lay as an alcoholic cinder in the nearest churchyard" (Thomas, 1955, p. 252).

Quote from The Morning and the Evening of a Day in Chapter 4

Clym Yeobright returns from Paris after receiving good education. He was originally a literate, unique, and gentle man, drawing so much attention from other girls on the hearth. He hopes to spread education by opening up a school, just like John the Baptist, not so much as advising others to repent and mend, but 
introducing the advanced ethical system prevailing in Paris to his compatriots. He is reluctant to see that as St. Paul says the whole creation groaning and travailing in the pain. He acts like a perfect man who throws away individuality, but seeks welfare for others. Such behavior corresponds to the philosophy of benevolence. He struggles to read more books to achieve the goal of propagating the knowledge and wisdom to households. Unluck falls upon him in succession and his mother's death shoots him into redemption and regret, he cannot run away from spiritual relaxation and sublimation but struggle under the umbrella of biblical philosophy.

Eustacia Vye, whom I think is a thought-provoking and warm-hearted female, never submits to the Edgon customs and longs to run away from the convention. She falls in love with Clym, a fresh comer, and expects to accompany him to Paris to enjoy the affluent life. What she pursues is mundane romance and personal happiness, warring against the philosophy of sensual passion suppression. Another one we should care is that from beginning to end she has never evaded the philosophy of biblical spirits. She fails to erase the memory of the death of Clym's mother, all of which result from her sense of sins, and she wants to redeem and repent what she has done wrong, yet Clym's objection and rude manner disappoints her and prevents her from finding the comfort and redemption of soul and spirit. Finally, she grows into abnormal condition and herself loses the new rebellious image and opts to turn blind to past sadness, tragically ending with drowning, which seems so usual.

Thomasin Yeobright, in contrast with Vye Eustacia, is a peaceful and traditional female and all time wants to seek a plain life. She gives up personal desire but to balance others' profits and create peace among them. She obeys the rule of the reality and keeps the principle and morality of being a wife. At last, she ends with a deep lover, Venn, who attends to her all the way. That is why she cares about nearly everyone by her and never loses the belief in god that would bless her. Venn acts like an angel that blesses and protects her and brings the final happiness to the girl, a perfect female by the principle of The Bible. The Return of the Native tells us that God will always bless those who keep faith and hold on to the belief when portraying such a character ThomainYeobright.

Most of other characters, such as Christian, Venn, Fairway, and Grandefer Cantle who live in Edgon Heath, instructed by biblical customs and philosophies all maintain the convention. But the character like Mr. Wildeve assumes the air of greed, selfishness, and irresponsibility against the biblical philosophy of the pure, kind, and generous heart. Such is a man, a representative of the evil man, who should be disagreed and condemned in The Return of the Native which contradicts the biblical philosophy. The Return of the Native displays a picture of Edgon where different people live in the same biblical context, but show different responses to what they are facing.

\section{Biblical Prototypes in The Return of the Native}

Biblical prototypes mean a use of symbol and metaphor. Not only will it bring interest, but also further the metaphorical meaning of the whole text. Various prototypes from The Bible will pass on the profound theme and artistic effect to join together to create an artistic world (ZHANG, 2005). Maybe we can believe Thomas Hardy unconsciously uses such biblical prototypes, because he originally wears a biblical face as I have said before, however, I wish more of his purpose of theme decoding and artistic effects. So many biblical prototypes in The Return of the Native bring Christian essence to the creation of this novel. The biblical prototypes can be classified into character prototypes, image prototypes, event prototypes, and thematic prototypes. Here I want to take some examples to make detailed analysis of the biblical prototypes in The Return of the Native about how they portray characters, create atmosphere, and enhance artistic effects. 
(1) "Had she been a mother she would have christened her boys such names as Saul and Sisera in preference to $\underline{\text { Jacob }}$ or David, neither of whom she admired" (Thomas, 1955, p. 78).

Quote from Queen of Night in Chapter 1

From character prototypes in the Bible, we can see how a man it is that Eustacia desires. She shows little interest to those religious and piteous men, but prefers those strong-willed and sentimental men of stern nature. Eustacia, a sharply unique female image on Edgon Heath, wavers nothing of what she desires and passes it to their next generation. This marks the certainty of collaboration of Eustacia and Clym and the beginning of a tragedy that is in principle.

(2) "My hook and gloves are like the St. Lazarus rattle of the leper, warning the world to get out of the way of a sight that would sadden them" (Thomas, 1955, p. 292).

Quote from She Goes Out to Battle Against Depression in Chapter 4

The biblical event comes from Gospel of Luke, meaning that Clym suffers a lot from his blindness mentally and physically. But he is rejoiced that Eustacia keeps companying him and brings him light of survival just as such a man affected with favus is protected by St. Lazarus. As it is, Eustacia not only faces the disillusioned but also bears the mental burden, predicted that she will go out. Clym is lost in hopelessness after he hears the truth of mother's death because he respects Eustacia as the illuminating and guiding light for his life. This covers a thick pessimistic atmosphere on the development of The Return of the Native.

(3) "Eustacia was always anxious to avoid the sight of her husband in such a state as this, which had become dreadful to her as the trial scene was to Judas Iscariot" (Thomas, 1955, p. 351).

Quote from Wherefore Is Light Given to Him That is in Misery in Chapter 5

This biblical event comes from Matthew, meaning that Clym's mother's death leaves a wound at the bottom of his heart, but causes huge damage to family relation. Their relationship can no longer be as before, but keeps in tense and tortured context. Their martial relationship comes to fall apart and the return of the native gradually enters into tragedy.

(4) "Wherefore Is Light Given to Him That is in Misery" (Thomas, 1955, p. 348).

Quote from Wherefore Is Light Given to Him That is in Misery in Chapter 5

The biblical events and thoughts, a title in Chapter 5, come from The Book of Job. Clym has a similar experience just like Job has undergone. They all weep for the unfairness of life and repent all they have done and endured. Job's submission to God reveals where Clym goes. Clym can do nothing but to accept misery, waiting the salvation of God.

\section{Conclusions}

The novel ends with unhappiness, meaning that human's life always has no nice ending. For those people who follow the old tradition and perform by the biblical rules, they can live a peaceful life but enclosed in a huge hearth for long. However, for those who expect to run for a new fresh life out of the familiar environment, they are bound to death. Biblical philosophy nearly fills in all parts of the novel as if to control each people's soul on the hearth whether they want to stay or not. That predicts the biblical philosophy rooted in each person pushes the development of the ending of the novel. Maybe a man can never violate the nature and regularity of society and human's development and all violations at last will come into non-beings, whatever the specific ending is. At that era, each man is living in biblical philosophy, as a representative of social culture and human cores, and how they perform will guide where they go. 


\section{References}

CHEN, G. M. (1999). The ways that British and American writers borrowed biblical stories. Anqing Normal College Journal, 1,104-109.

LIANG, G. (2008). On the literature qualities of the Bible. Foreign Literature, 5, 74-79.

MA, X. (2003). On religious thoughts of Thomas Hardy. Foreign Literature Review, 4, 115-122.

Thomas, H. (1955). The return of the native. New York: Washington Square Press.

ZHANG, Q. M. (2005). On the metaphor and symbol in Hardy's novels. Shenyang Normal University Journal, 3, 117-120.

ZHU, W. Z. (1982). The status and nature of biblical literature. Foreign Literature Studies, 4, 45-49. 